\title{
Paul W. Bennett \\ Vanishing Schools, Threatened Communities: The Contested Schoolhouse in Maritime Canada, 1850-2010
}

Halifax: Fernwood Publishing, 2011. x, 199 pp.

\author{
J. Donald Wilson \\ University of British Columbia
}

As a born and bred Ontarian and later a transplanted British Columbian, my knowledge of public education in nineteenth century Maritime Canada was largely derived from reading William B. Hamilton's excellent chapters in a book I helped edit in the late 1960s (Canadian Education: A History, 1970). Now Paul Bennett has filled this lacuna with a solid, well researched historical account of public education in Maritime Canada from 1850 to 2010. But that's not all: Bennett uses his history to supplement a sustained appeal to parents and the general public to question seriously the validity of the current widespread bureaucratic conviction that "bigger is better" in respect to the nationwide trend towards rural school closing and school consolidation. School closing issues, he argues, centre around not only heritage preservation and local control over public education (the school as a "social anchor") but the quality of education to be found in small schools. Citing the work of social historian Michael Corbett and the Corbett-Mulcahy Report of 2006, Education on a Human Scale, Bennett challenges the common assumption that school consolidation is synonymous with school improvement, and instead, follows Corbett and Mulcahy's assertion that "small schools do a better job of educating children... and particularly those children who live in conditions of economic disadvantage" (170).

Drawing heavily on the interpretative frameworks created for nineteenth century Ontario by Bruce Curtis and Alison Prentice, Bennett creates a similar picture for the three Maritime Provinces. The nineteenth century schooling project was central to the making of the modern state in Canada. Inspired by Enlightenment thinking, school promoters like Joseph Howe, Alexander Forrester, William Dawson, Theodore H. 
Rand and Marshall d'Avray (not mentioned by Bennett) led the campaign for public schooling and eventually compulsory education in the Maritimes. If children could acquire the "right" kind of ideas, human beings could make steady progress towards a state of social perfection. These ideas belonged to an elite of middle-class thinkers who were champions of individualism, private property and the free market as well as justice, liberty and human rights. In a paternal, top-down sort of way, the behaviour of the common people would be influenced for the better. Thus was established the origins of the modern state. The rest of Bennett's book seeks to demonstrate to the reader how these "modern" ideas centred in the public school took hold in Maritime Canada and elsewhere and essentially remain with us to this day. Notions such as "bigger is better" and "everything new is by definition better" took a firm hold in the minds of politicians and educational bureaucrats and help to account for much of the course of public education over the past century and a half.

A second theme in Bennett's comprehensive account is the evolution of school design and school architecture in Maritime Canada, a much neglected topic in Canadian educational history. Again, the influence of American Henry Barnard's School Architecture (1842) and Ontarian J. George Hodgins' The Schoolhouse: Its Architecture, External and Internal Arrangements (1857) is made manifest. Bennett carries the story forward from the emphasis Egerton Ryerson placed on the importance of a proper schoolhouse in every community. He reminds us that "school designs... resembled small cathedrals on the outside but operated on the inside much like factories" (6). In their era the courthouse, church and schoolhouse became the vital centre of community life. With the aid of numerous well-chosen illustrations, Bennett then traces the evolution of school design over a century from the "palace schools" of the early twentieth century to the "egg crate" functional schools of the 1950 s to the "big-box" schools of the late 1970s and 1980s intended to accommodate the "open concept" plan then in vogue. The last school photograph in the book shows a modern Halifax secondary school looking like a "gleaming glass covered airport terminal" (172).

A third theme, again well developed, is the influence of progressive education on public education in the Maritimes in the pre-World War I and the interwar period. Here we learn how the Maritimes adopted many features of progressive education from vocational and technical education to school consolidation, extension of secondary education, and important pedagogical changes. The Macdonald-Robertson movement experienced considerable success in the Maritimes, while Nova Scotian Loran De Wolfe, a prototypical progressive reformer, "espoused a progressive education philosophy considered radical at the time" (51) in his capacity as a normal school instructor, head of the new Division of Rural Science and director of rural education (1926-43). Latterly, Ontario's Hall-Dennis Report (1968) with its emphasis on child-centred learning made significant, if temporary, inroads on the educational systems of Nova Scotia and New Brunswick; less so in Prince Edward Island.

A few errors and omissions might be noted, but not many in this well-researched and carefully crafted account. The author seems unacquainted with the extensive literature on one-room schools written by several British Columbian historians, such as 
Thomas Fleming and Paul Stortz, in the last twenty-five years not to mention Patrick Dunae's valuable website on B.C. schools. And Michael Katz's contention regarding common school reform referred to the mid-1800s, not mid-1900s (111). On page 131 Wheelock and Wheeler are surely one person. Finally, the discussion on pages 173 to 175 of the rural school backlash on Prince Edward Island in recent years, while important, is confusing and lacking sufficient detail for the reader unfamiliar with local issues.

Vanishing Schools, Threatened Communities is a fine piece of historical writing drawing on a vast array of primary and secondary sources. The author, who earlier benefited from the caring mentorship of Alison Prentice at O.I.S.E., is well acquainted with the historiography of Canadian education, and obviously has a deep love of the cultural history of Maritime Canada, particularly the rural areas. The book merits attention from both academic and popular historians, not to mention contemporary school activists attempting to hold the fort against the onslaught of educational bureaucrats bent on school consolidation in the name of "bigger and better" schools. Overall the book provides a much-needed account of a region of Canada largely overlooked in nation-wide accounts of Canadian history.

As Corbett and Mulcahy conclude, school administrators "often have something very different in mind when they speak of educational quality than the images of educational quality in the minds of most citizens living in rural communities." In this fine example of "usable history," Bennett in the end calls upon readers to regain control over schools, rebuild "social capital" and revitalize local communities. Let's hope Canadians are listening. 